\title{
Left Coast Political Ecology: a manifesto
}

\author{
Ashton Wesner ${ }^{\mathrm{b} 1}$ \\ Sophie Sapp Moore ${ }^{\mathrm{c}}$ \\ Jeff Vance Martin ${ }^{\mathrm{b}}$ \\ Gabi Kirk ${ }^{\mathrm{a}}$ \\ Laura Dev \\ Ingrid Behrsin $^{\mathrm{a}}$

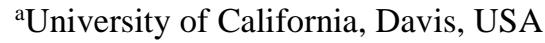 \\ bUniversity of California, Berkeley, USA \\ 'University of Wisconsin-Madison, USA
}

\begin{abstract}
Left Coast Political Ecology (LCPE) is a network of undergraduate and graduate students, postdoctoral scholars and faculty engaged in a collective practice of political ecology grounded in strong connection to the "Left Coast" of North America. In this manifesto, we build on successful 2015 and 2018 workshops on the practice and value of political ecology today to communicate our origins, efforts, and ideas towards building a community of praxis amid the urgencies and uncertainties of our time. We first articulate those organizing and theoretical lineages that influence and inform our work. We trace the evolution of LCPE through diverse genealogies and cross-pollinations - from the "Berkeley School" to Black, Indigenous, feminist, and decolonial studies, through political struggles within and beyond the academy. In grappling with the challenges of our institutional histories of settler-colonial, capitalist, and racist dispossession, we then propose a "coastal epistemology", one that troubles the notion of a settler-colonial or neoliberal "frontier" while finding value in encounter, conversation, and emergence. We seek to make transparent our positions of relative privilege as well as the precarious contexts in which we work and live, while mobilizing and embodying political ecology's long-standing normative and liberatory aims. Next we share some of the diverse methodological approaches employed by our members and collective, with the aim of providing
\end{abstract}

\footnotetext{
${ }^{1}$ Each author made an equal contribution to this article, which we publish on behalf of the Left Coast Political Ecology Network. Authors, listed in reverse alphabetical order, are: Dr. Ashton Wesner, Visiting Faculty in STS/History of Science, Department of History, University of California, Berkeley, USA. Email: ashton.wesner "at" berkeley.edu. Dr. Sophie Sapp Moore, Postdoctoral Fellow, Nelson Institute for Environmental Studies, University of WisconsinMadison, USA. Email: slmoore5 "at" wisc.edu. Jeff Vance Martin, PhD Candidate, Department of Geography, University of California, Berkeley, USA. Email: j.vance.martin "at" berkeley.edu. Gabi Kirk, PhD Candidate, Geography Graduate Group, University of California, Davis, USA. Email: gekirk "at" ucdavis.edu. Laura Dev, PhD Candidate, Department of Environmental Science, Policy, and Management, University of California, Berkeley, USA. Email: lauradev "at" berkeley.edu. Dr. Ingrid Behrsin, Postdoctoral Fellow, Public Scholarship and Engagement, University of California, Davis, USA. Email: iabehrsin "at" ucdavis.edu. Acknowledgements: The authors are deeply grateful, first, to the activists and community partners who inspire and ground Left Coast Political Ecology's work. We would also like to thank the faculty mentors who contributed the intellectual support and the institutional resources necessary to begin building our network. We likewise acknowledge the time and energy that UC Berkeley and UC Davis staff have contributed to our campus events, as well as the continued dialogue and support shared between the faculty and students who make up LCPE's broader network. Finally, the authors would like to thank JPE editors Casey Walsh and Simon Batterbury for their guidance, as well as the three anonymous reviewers whose comments were invaluable in developing this article.
} 
inspiration and solidarity to others contending with similar challenges. Ultimately, we suggest a vision for what a political ecology adequate to our moment might look like and require: a necessarily collective and hopeful project, amid processes of colonial violence, capitalist inequity, and climate catastrophe. The Left Coast Political Ecology network invites you to dream and organize with us, to share resources, experiences, and community, and to help push our field and our institutions toward more socially just and ecologically sustainable futures.

Keywords: Coastal epistemology, Left Coast, network, radical geography, praxis, West Coast

\section{Résumé}

L'écologie politique de la côte gauche (LCPE) est un réseau d'étudiants de premier cycle et des cycles supérieurs, de postdoctorants et de professeurs engagés dans une pratique collective d'écologie politique fondée sur des liens étroits avec la «côte gauche» de l'Amérique du Nord. Dans ce manifeste, nous nous appuyons sur nos ateliers de 2015 et 2018 sur la pratique et la valeur de l'écologie politique aujourd'hui pour communiquer nos origines, nos efforts et nos idées en vue de créer une communauté de praxis face aux urgences et aux incertitudes de notre temps. Nous articulons d'abord les lignages organisationnels et théoriques qui influencent et informent notre travail. Nous suivons l'évolution de la LCPE à travers diverses généalogies et pollinisations croisées - de «l'école Berkeley» aux études afro-américaines, autochtones, féministes et décoloniales, en passant par les luttes politiques au sein et au-delà de l'académie. En abordant les défis de nos histoires institutionnelles de dépossession coloniale, capitaliste et raciste, nous proposons ensuite une «épistémologie côtière», qui trouble la notion de «frontière» coloniale ou néolibérale, tout en trouvant de la valeur dans la rencontre, conversation et émergence. Nous cherchons à rendre transparentes nos positions de privilège relatif ainsi que les contextes précaires dans lesquels nous travaillons et vivons, tout en mobilisant et en incarnant les objectifs normatifs et libérateurs de l'écologie politique. Ensuite, nous partageons certaines des approches méthodologiques utilisées par nos membres et notre collectif, dans le but de fournir inspiration et solidarité aux autres personnes confrontées à des défis similaires. En fin de compte, nous proposons une vision de ce à quoi pourrait ressembler une écologie politique adaptée à notre moment et ce qu'elle pourrait nécessiter: un projet nécessairement collectif et plein d'espoir, au milieu de processus de violence coloniale, d'inégalités capitalistes et de catastrophe climatique. Le réseau d'écologie politique de la côte gauche vous invite à rêver et à organiser avec nous, à partager des ressources et des expériences en communauté, et à aider à faire progresser notre domaine et nos institutions vers un avenir plus juste, socialement et écologiquement durable.

Mots-clés: épistémologie côtière, côte gauche, réseau, géographie radicale, praxis, côte ouest

\section{Resumen}

Left Coast Political Ecology (LCPE) es una red de estudiantes, académicos posdoctorales y docentes que participan en una práctica colectiva de ecología política basada en una conexión profunda con la "Costa Izquierda" de América del Norte. En este manifiesto, se elabora con base en los exitosos talleres realizados en el año 2015 y 2018, donde reflexionamos sobre la práctica de la ecología política y el valor que tiene hoy como estrategia idónea para comunicar nuestros orígenes, esfuerzos e ideas para construir una comunidad de praxis en medio de las urgencias e incertidumbres de nuestro tiempo. Primero que todo articulamos aquellos linajes teóricos guía que influyen e informan nuestro trabajo. Trazamos la evolución de LCPE a través de diversas genealogías y polinizaciones cruzadas, desde la "Escuela de Berkeley" hasta los estudios afro-descendientes, indígenas, feministas y decoloniales, a través de luchas políticas dentro y más allá de la academia. Al abordar los desafíos de nuestras historias institucionales de despojo colonial, capitalista y racista, proponemos una "epistemología costera", una que perturba la noción de una "frontera" colonial o neoliberal a la vez que encuentra valor en el encuentro, la conversación y la emergencia de lo posible. Buscamos hacer transparentes nuestras posiciones e identidades de relativo privilegio, así como los contextos precarios en los que trabajamos y vivimos, mientras movilizamos y encarnamos los objetivos normativos y liberadores de la ecología política. Posteriormente, compartimos algunos de los diversos enfoques metodológicos empleados por nuestros miembros y el colectivo en general, con el objetivo de proporcionar inspiración y solidaridad a otras personas que enfrentan desafíos similares. Por último, sugerimos una visión de cómo podría ser y lo que podría requerir una ecología política adecuada para nuestro momento: un proyecto necesariamente colectivo y esperanzador, en medio de procesos de violencia colonial, desigualdad capitalista y catástrofe climática. La red de Left Coast Political Ecology invita a la gente a soñar y organizarse con nosotros/nosotras, a compartir recursos, experiencias 
y redes comunitarias, y a ayudar a impulsar nuestro campo de estudio y nuestras instituciones hacia un futuro más justo socialmente y más sostenible ecológicamente.

Palabras Clave: Epistemología costera, costa izquierda, red, geografía radical, praxis, costa oeste

\section{Welcome to the Left Coast}

The coast is an edgy place. Living on the coast presents certain stark realities and a wild, rare beauty. Continent confronts ocean. Weather intensifies. It's a place of tide and tantrum; of flirtations among fresh- and saltwaters, forests and shores; of tense negotiations with an ocean that gives much but demands more. Every year the raw rim that is this coast gets hammered and reshaped like molten bronze. This place roils with power and a sometimes terrible beauty. The coast remains youthful, daring, uncertain about tomorrow. The guessing, the risk; in a way, we're all thrill seekers here.

Carl Safina, The view from Lazy Point: a natural year in an unnatural world, 2012

In these times of uncertainty, political ecologists find themselves in an edgy place. Under conditions of ongoing capitalist, racist, patriarchal, and settler-colonial transformations of nature and society, political ecology should be risky. That is, work on the brink demands a praxis that both takes risks and puts itself at risk. Left Coast Political Ecology (LCPE) is a network of political ecologists -undergraduate and graduate students, postdocs, and faculty - who are engaged in a collective practice of political ecology on the edge. We live on, work in, or have other strong connections to the "Left Coast." At the same time, LCPE undertakes an ongoing process of inquiry into the tensions inherent in working from this edgy place.

What does "Left Coast" mean for us? Initially, the name alluded playfully to both the West Coast location of our original organizing core (primarily, University of California, Berkeley; University of California, Davis; and Portland State University), and to political ecology's roots in leftist political critique. In the past three years, however, we have pushed ourselves to contend more deeply with and across these geographic and intellectual boundaries. Coasts are edges: of a land mass, or of knowledge and cultural innovation. Coasts are borders: of a nation-state, or the outer reaches of a discipline. In the U.S., coasts are proudly or derogatorily hailed as the spaces of a certain kind of political identity and knowledge production. Thus, normative notions of coasts - as boundaries and sites of confluence - trouble and motivate our inquiries. From the Left Coast, we build on and challenge the discipline's traditions as we seek to practice a political ecology adequate to our current moment.

In the political imaginary, the West Coast offers a generative geography for leftist struggles and liberatory world-building. The long-standing tradition of radical geographic scholarship rooted in the University of California (UC) system has been an important articulation of the intersection between environmental scholarship and activism. ${ }^{2}$ LCPE grows directly out of this genealogy of action-oriented, problem-based political ecology. Yet LCPE also challenges today's political ecologists to work at those jagged edges where foundational struggles for racial, gender, and environmental justice embed the Left Coast in broader geographies of local and global change (Blue Cloud 1972; Flores 2016; Hernández 2015; Johnson 1996; Stryker 2008).

Notwithstanding the West Coast's history of left struggle, however, the region is no less marked by a legacy of settler-colonial, racist, and capitalist structures and acts of violent enclosure and dispossession. The material histories of the West Coast have been shaped by the displacement and genocide of Indigenous peoples, justified through narratives of Manifest Destiny and dreams of conquering a fertile frontier. Tensions surrounding the governance of vast swathes of Western public lands, as landscapes of

\footnotetext{
${ }^{2}$ See, for example, collective endeavors like the Center for Ecological Socialism (known as the Center for Political Ecology since the early 1990s), the Center for Agroecology and Sustainable Food Systems at UC Santa Cruz, and the Berkeley Workshop on Environmental Politics (see Section 2, below). Many of LCPE's mentors were instrumental in these undertakings.
} 
conservation and resource extraction that reshaped environments to fit European ideals, continue to play out in the present (Cronon 1992; Hays 1999; Meinig 1972; Wilkinson 1992). The West Coast and its universities are built on and have directly benefited from dispossession and enslavement of Native nations, racist immigration restrictions placed on Chinese workers, internment of Japanese-Americans, redlining against African-Americans, and exploitation of Mexican and Central American labor (Bauer Jr. 2016; Daniel 1982; Flamming 2005; Gilmore 2007).

The mission of the public land grant university - such as the University of California, where the authors have or will complete their PhDs - mobilizes a conception of the public good that remains in tension with the histories of dispossession that shape the geography of the West Coast. Agricultural development, including research funded by and conducted at land grant universities continues to drive economic and racial exploitation (Walker 2004). This historic and ongoing violence is the foundation of university resources that support LCPE's scholarship and our network's very existence; this is something we cannot escape. Particularly within political ecology, there is renewed attention to public universities' responsibility to conduct politically engaged research at this political moment of increased repression (Goldstein, Paprocki and Osborne 2019). At this crucial moment, however, we also call for a critical ambivalence towards public scholarship, asking how various "publics" both within and outside of our universities have historically been defined and excluded (Middleton Manning 2018), and how we can collectively expand and reform our material, scholarly and ethical accountabilities. We therefore ask what it means to work from this edgy place, and we insist that the edge itself matters. LCPE thus builds on previous institutional efforts to engage the public in environmental research by foregrounding the reparative potential of political ecology as a radical praxis.

Our conception of "Left Coast" does not aim to create a coastal "frontier" that replicates settlercolonial and neoliberal capitalist ideas of discovery and innovation. Instead, we can and should take a "hatchet" to these structures, and through our collaborative work help to build something different (Robbins 2012). LCPE builds on past challenges to the conception of "the political" within political ecology itself (Walker 2007). Our commitment to unsettling ongoing patterns of violence and inequalities through collective practice carries on our mentors' work. Although many LCPE members conduct research or work abroad, part of our network's practice is to turn our attention and resources to the struggles going on in the lands we call home (cf. Martin et al. 2019; McCarthy 2002; Robbins 2002; Schroeder et al. 2006). At our January 2018 workshop at UC Berkeley, we were inspired to do more than simply acknowledge our presence on Chochenyo and Karkin Ohlone Lands (Vowel (Âpihtawikosisân) 2016), instead contributing a portion of our collected funds as reparations to the Sogorea Te' Land Trust and Anti Police-Terror Project. $^{3}$

The urgency of LCPE's project is clear. Climate catastrophe is not a hypothetical future threat, it has already arrived on the Left Coast. Worsening wildfires, droughts, and other (not-so) natural disasters are coupled with a dire housing crisis across our cities (M. Davis 1998; Simon 2016). Racialized capitalist development accumulates wealth in the hands of the few and makes our cities increasingly unlivable for working-class communities of color. Meanwhile, an already diminished water supply is funneled away from native territories to support the expansion of industrial agriculture (Kahrl 1983; Middleton Manning 2018). Similar crises of nature, power, and capital figure centrally in the work of liberation ecologists of preceding generations (e.g. Peet and Watts 2004). Yet as recent debates around the "-cenes" Anthropocene, Capitalocene, and Plantationocene, to name a few (Haraway 2015; Moore et al. 2019) suggest, the current conjuncture challenges political ecologists to engage with anticolonial, antiracist, and anticapitalist praxes in new ways.

The members of our network do not just watch and critique these events as intellectual observers. We breathed in smoke and had our campuses closed due to fire threat; our loved ones lost homes to fire or

\footnotetext{
3 "The Sogorea Te Land Trust is an urban Indigenous women-led community organization that facilitates the return of Chochenyo and Karkin Ohlone lands in the San Francisco Bay Area to Indigenous stewardship (Sogorea Te 2018). The Anti Police-Terror Project is a "Black-led, multi-racial, intergenerational coalition that seeks to build a replicable and sustainable model to eradicate police terror in communities of color" (Anti Police-Terror Project 2018).
} 
eviction; we have been directly targeted for repression and harassment by the alt-right; and we worry about the precarious future of the public university. Nonetheless, we find ourselves in a privileged position within this edgy place. Political ecology, and its cognate disciplines (geography, anthropology, and the environmental and social sciences more broadly), is a historically white-dominated field (Biersack and Greenberg 2006; Escobar 1998, 1999; Faria and Mollett 2016; Pulido 2002). LCPE's network is likewise predominantly white. Yet at the same time, we find the places we work for and from to be at ever-greater risk. LCPE scholars situate our own precarity within a collective future that grows ever more uncertain.

LCPE is committed to a liberatory praxis that combines normative research and political engagement. Attempting to put this into practice at the current conjuncture, however, can be perilous. The rise of right-wing neo-fascism locally and globally is evident even, or especially, in the "progressive bastions" of North America, as seen in the 2017 clashes in Berkeley against alt-right forces. ${ }^{4}$ A more insidious example is geographer Scott Warren's prosecution related to his provision of food and water for migrants at the US border. Warren's arrest illustrates the urgency and the risks of political ecologists' obligation to work from and for edgy places (Krohn 2019).

LCPE's praxis is also aligned with interdisciplinary programs founded in the 1990s, like Ethnic and Cultural Studies, that worked to embrace a public and engaged scholarship. At the UC, such programs drew on the historic strengths of the land grant university to address pressing social and environmental issues. In so doing, however, they had to negotiate the promise and peril of the public university: its aspiration to do collective social good, but also the exclusionary history of the public institution. LCPE thus seeks to use our institutional, intellectual, and positional privileges to engage with the struggles that surround us and affect our communities. We must continue to build relations and keep them close. Rather than conceiving of ourselves as allies in the struggles of others, we aspire to follow the leadership of the communities most impacted to approach the material realities of environmental violence and racism through a vision of collective liberation.

The Left Coast Political Ecology network invites you to dream and organize with us, to push our field and our institutions to build toward a more socially just and ecologically sustainable future. One form our invitation takes is this manifesto, in which we articulate the theoretical and organizational histories that inform our work and our future direction. We aim to make transparent some of the struggles we encounter, and to provide inspiration to other collectives contending with the edginess of radical scholarship and political action, both within and beyond academia. In this piece, we chronicle the origins and evolution of the Left Coast Political Ecology network, explore the opportunities and limits that coastal epistemologies offer and the methodological approaches our praxes take, and suggest a vision for what a future Left Coast political ecology might look like.

\section{Radical geography on the Left Coast}

Political ecology, according to Robbins (2012: 25), is "a tree with deep roots." It is, moreover, a contact zone between disparate strands, an ongoing and shifting conversation around the critical analysis of nature-society relations held among fields and scholars. Political ecology's genealogy draws from geography, anthropology, and beyond to explore how "politics is inherently ecological, [and] ecology is inherently political" (Robbins 2012: 3). The "Berkeley School" of political ecology, for example, built on the fruitful convergence of Marxist theories of political economy with interventions from cultural ecology and Sauerian historical geography (Sauer 1963; Steward 1972). We focus on Berkeley because this institution in particular served as an important crucible and training ground for several waves of critical scholars of the environment, who were also engaging with political movements and commitments beyond the academy (Merchant 2005; Peet and Watts 2004; Zimmerer 1995). ${ }^{5}$ Many of our own mentors have been

\footnotetext{
${ }^{4}$ Berkeley was specifically targeted by alt-right protestors because UC Berkeley had a very strong "antifa" response to Milo Yiannopoulos' planned speaking engagement in February 2017.

${ }^{5}$ There are, of course, numerous other "centers" of political ecology around the world. Graduates of and faculty in programs including ESPM, Geography, and Urban Planning at UC Berkeley and UCLA have been integral to the
} 
influential in the iterations of political ecology's development during and since the 1970s. In addition to the intellectual influence of the Berkeley School on much of our membership, logistical and financial support from key figures like Michael Watts and Nancy Peluso (from the Environmental Politics Workshops) have made LCPE's workshops possible. ${ }^{6}$

At Berkeley in the 1970s, a cohort of scholars - particularly from the Departments of Geography, City and Regional Planning, and Agricultural and Resource Economics - began developing a leftist geographic praxis in response to the social and political climate of the time (Peck and Barnes 2019). Such conceptual work invariably involved policy advocacy and political campaigns, grassroots activism, and building projects for radical alternatives. Many students and faculty were politicized off-campus or outside of the aforementioned departments, bringing counter-cultural critiques from broader Bay Area struggles of the time, especially from Third World student, environmental, anti-war, civil rights, and women's rights movements. Emerging from this history, West Coast political ecology has maintained its normative and liberatory commitments to social justice, local and transnationally oriented social movements, and offcampus collaboration that have continually evolved in response to the contemporary political moment (Peck and Barnes 2019; Peet and Watts 2004).

Early political ecology responded to an interdisciplinary need for a framework to understand the relations between capital and nature (Blaikie 1985; Blaikie and Brookfield 1987; O'Connor 1988; Watts 1983). Political ecologists of this tradition have pushed back against conventional understandings of environmental degradation, arguing for new approaches to understanding the complex relations between resources and conflict that upended predominant assumptions of direct causality between population growth, resource scarcity, and violence (Peet and Watts 2004; Peluso 1992; Peluso and Watts 2001). Some demonstrated the urgency of questioning accepted stories about environmental decline, revealing the persistence of erroneous narratives used to justify the suppression and exploitation of oppressed peoples in the name of environmental protection (D.K. Davis 2007; Sayre 2002). Others focused on the entanglements of race, gender, class, and nation that animate the material and symbolic production of "nature" (Kosek 2006; Rocheleau and Edmunds 1997), and sharpened interdisciplinary analyses of how race and nature function as terrains of power (Moore, Kosek and Pandian 2003). Taking account of these contributions at the turn of the $21^{\text {st }}$ century reveals a commitment to critical historical analysis that traces the convergence of power relations and methods of resistance (D.K. Davis 2015; Sayre 2017).

While the field has been politically engaged from its inception, political ecology has also sustained critiques for its lack of attention to the politics and ethics of its own research practices, in particular its lack of engagement with publics beyond the academy (Blaikie 2008; Rocheleau 2008). LCPE's reparative praxis brings political ecology's normative commitment to social change to bear upon the discipline's own entanglement with systems and structures of capitalist, patriarchal, and colonial domination. At the same time, in theoretical terms LCPE's coastal epistemology builds on work that reflects critically on the Eurocentric and colonial foundations of social scientific theory and research methods (Louis 2007; Santos 2014; Smith 2012).

Political ecologists are increasingly pushing the field's long-standing normative commitment to social change to contend with race, gender, class, and their intersections in new ways (Doshi 2017; Heynen 2018; Middleton 2010, 2015; Mollet and Faria 2013; Moore and Robbins 2015). LCPE takes up a recent call for a decolonial political ecology (Carroll 2015; Kim et al. 2012; Schulz 2017; Sundberg 2014) and treats this as a methodological challenge. We are inspired by precedents like the Center for Political Ecology ${ }^{7}$ in our commitment to work that is reparative and collaborative across institutional lines. But at

development of such centers, particularly on the West Coast. See, for example, the work of Judith Carney and Susanna Hecht at UCLA.

${ }^{6}$ See Section 3 for more detailed information on our annual workshops.

7 The Center for Political Ecology (CPE) is a Santa Cruz, California based non-profit organized as an online collective of "scholar-advocates" who conduct collaborative, action-research. They "generate independent and credible research on environment, health and human rights in local and global contexts" and "their community-based work is typically conducted at the request and in collaboration with Indigenous peoples and other affected communities and groups who 
the same time, we take up a stance of critical ambivalence with respect to the academy. LCPE scholars' work engages long-standing traditions around land, environment, nature, and processes of socio-ecological change, particularly from Black and Indigenous thought. These traditions have been persistently ignored or structurally excluded from political ecology, or structurally segregated into subcategories instead of centered as foundational to political ecology theory and method (Finney 2014; Goeman 2013; McKittrick and Woods 2007; Middleton 2015; Murphy 2017; TallBear 2014; Robinson 1983; Wynter 1971, 2003).

Today political ecology scholarship and practice must engage fully in the immediate and sustained generation of ideas, imagining, and action toward antiracist and un-occupied futures in the U.S. and globally. Liberatory movements, demonstrations, and theorizations push political ecology to reckon with the limitations and possibilities of our scholarly practices. A commitment to political ecology's normative orientation compels us to intervene materially and ideologically in our moment's most urgent matters of life and death, harm and repair. Because the places we write from and for are edgy in very different ways, we also work to develop a network that itself challenges the limits that institutions place on radical, critically engaged scholarship.

\section{LCPE's coastal epistemology}

Coastlines, those edges where sea meets land, are shaped through erosion, a process of both erasure and revelation. LCPE mobilizes this double meaning of erosion in formulating a 'coastal epistemology' appropriate to our contemporary moment, both within and beyond the academy. We articulate a collective way of knowing at the nexus between the public universities of the West Coast and the particular forms of left politics emerging from the social and political struggles of this region over the late $20^{\text {th }}$ century. Yet a coastal epistemology also challenges us to reckon with the territories revealed by new and corrosive formations of power and capital. The genealogies that shaped political ecology as an academic field are themselves profoundly implicated in these same corrosive formations (see Gilmore 2007). Such entanglements compel us to deepen our engagement with other critical disciplines and movements, including those aligned with feminist, decolonial, and antiracist ways of thinking through socio-ecological problems (Kim et al. 2012; Restrepo and Escobar 2005; Sundberg 2007).

In seeking to forge an epistemological approach uniquely rooted in our Left Coast location, we must ask how our political commitments and entanglements affect the scholarly practices of research, writing, and engagement. LCPE understands political ecology as something people do - academics as well as those beyond the academy - rather than as a discrete body of knowledge (Robbins 2012: 4). A coastal epistemology inhabits this zone of encounter, looking to diverse influences to produce the next wave of political ecology praxis. Like the West Coast radical scholars who came before us, and the scholaradvocates and activists with whom we align in local and global networks today, we are furthering forms of intellectual engagement that take place on campus, in our homes, and online. Therefore, LCPE's coastal epistemology foregrounds collaborative engagement with community political struggles as an explicit component of engaged scholarship.

Inspiring new political ecology work has asserted critical theorizations of, and called for sustained action against the socio-ecological and spatial dimensions of, white supremacy (Pulido and De Lara 2018). LCPE's work to put our coastal epistemology into practice resonates with such calls. For instance, one of this article's authors entered graduate school to research environmental justice issues in Israel-Palestine, building on years of work organizing for justice for Palestinians. For this scholar, a coastal epistemology opens up deeper analysis of the "zone of encounter" formed by transnational material flows of capital and power relations of discourse between the West Coast and Israel-Palestine. A coastal epistemology also keeps them rooted in accountability to local communities near their home who are struggling for justice, as well as those on the ground in Israel-Palestine.

seek to restore the fundamental rights to a healthy environment through research and action" (www.centerforpoliticalecology.org). 


\section{Left Coast Political Ecology: a network genealogy}

Left Coast Political Ecology's history has been one of emergence. Early LCPE organizing built on paths carved by the institutional groups and centers that came before us. Many such antecedents had trained our own doctoral advisors, and have subsequently provided us with key logistical and financial resources. These included the Workshop on Environmental Politics at UC Berkeley, ${ }^{8}$ the Ecosystem Services Supporting Urbanizing Regions (ESUR) NSF-funded IGERT program at Portland State University ${ }^{9}$, and the political ecology 'surgery' at UC Davis. ${ }^{10}$ However, LCPE scholars also convened around a desire to fill the gaps left between and in the aftermath of these groupings, many of which had ebbed by 2012. The Berkeley Workshop on Environmental Politics, for example, was founded by faculty with shared interests in questions of nature, culture, and power. From 1996 until 2012, this group convened faculty, students, and visitors for colloquia and workshops on writings-in-progress. ${ }^{11}$ Always centered on the application of critical theory to environmental problems, and involving leading political ecology scholars and scholaractivists, the legacy of the Berkeley Workshop on Environmental Politics offered intellectual and financial scaffolding for LCPE to put roots-to-ground.

LCPE's founding members were motivated to address a lack of institutional continuity and a perceived dearth of resources and of conversations across departments and institutions. A desire to continue and to expand collaborations, to learn from one another, and to share resources led to early meetings between a handful of individuals from UC Berkeley, Portland State University, UC Davis, and then beyond. ${ }^{12}$ Building on connections made at interdisciplinary venues like the American Association of Geographers (AAG) annual meeting and the Dimensions of Political Ecology (DOPE) conference, we began a dialogue that extended beyond our home departments of geography, urban studies, environmental science, policy, and management, and cultural studies. Sharing a libation, breaking bread, and web-assisted conference calls beginning in 2014 laid the foundation for the network, connecting students and faculty across institutions as we learned our histories and began to build toward something new. Left Coast Political Ecology first came together in person at UC Berkeley in the spring of 2015. With financial support from the Berkeley Workshop on Environmental Politics and individual faculty members from three institutions, this one-day workshop convened approximately two dozen graduate students, ten faculty members, and postdocs from West Coast universities between British Columbia and the San Francisco Bay Area. Organizers were driven by a collective desire to address a perceived gap in political ecology graduate school training: the practicalities of doing and disseminating political ecology scholarship.

To address this gap, we organized panels on methods, epistemology and ontology, funding, and publishing. Our focus was explicitly on the 'nuts and bolts' of political ecology as practice, our objective to facilitate knowledge sharing among scholars employing a variety of methods - from soil sampling to ethnography - at different stages of their careers. Participants developed a more robust sense of political ecology methodology, but also began to build long-lasting interpersonal connections. Then, following the 2016 US Federal election, LCPE members were energized to re-engage with what had drawn many of us to political ecology in the first place: not just critique (the "hatchet") but also the potential for public-facing and normative scholarship (the "seed") that works for change beyond the academy (Robbins 2012).

In 2018 LCPE once more gathered in Berkeley, this time around the question of Why political ecology now? This three-day workshop drew together a new set of voices from cohorts and institutions beyond the early core. From a keynote lecture by Dr. Jade Sasser (Sasser 2018), to workshops highlighting

\footnotetext{
${ }^{8}$ http://globetrotter.berkeley.edu/bwep.

${ }^{9}$ https://www.pdx.edu/esur-igert/home.

${ }^{10}$ A group of LCPE's original organizers gathered in an informal political ecology/environmental history 'surgery' convened by Dr. Diana Davis in 2013. The surgery was a regular, informal meeting of UC Davis PhD candidates interested in feminist, Marxist, and decolonial political ecology. The surgery discussed current theoretical trends, shared works in progress, and shed light on the 'nuts and bolts' of political ecology in the academy.

${ }^{11}$ For more information on the Berkeley Workshop on Environmental Politics, the group's past activities, published works, and affiliates can be found here: http://globetrotter.berkeley.edu/bwep/index.php.

12 These efforts would eventually connect up with parallel conversations happening out of Portland State University, led between Dr. Nathan McClintock and then-visiting scholar at Stanford, Dr. Henrik Ernstson.
} 
cross-institutional mentorship, methods, and future directions, the gathering highlighted articulations of race, gender, more-than-human, anti-capitalist, and activist concerns within and beyond political ecology, and explored how political ecology could inform and come together around a praxis of resistance. Notably, the workshop supported the growth and strengthening of connections with other institutional and community-based efforts, including insight and inspiration drawn from the Public Political Ecology Lab at the University of Arizona and the open access Journal of Political Ecology (Osborne 2017). ${ }^{13}$

In addition to the expansion of our network and the collective's ongoing informal dialogue, at least three tangible outcomes have emerged from these workshops. First, multiple sessions at the AAG annual meeting and Dimensions of Political Ecology (DOPE) conference have been collaboratively organized each year since the first LCPE workshop in 2015. Second, we have provided each other with feedback beyond the immediate circles of individuals' departments or campuses, serving as preliminary peer reviewers of works in progress. Third, we have written collaboratively for peer-reviewed publications, this intervention serving as case-in-point. The 2018 workshop also generated several combined faculty/student funding proposals. Beyond cultivating additional skills and personal networks of political ecology comrades, our workshops and our dedication to collaborating and sharing resources have helped us 'get by' in an academic environment where success is usually measured through direct competition. Because LCPE scholars aim to conduct relevant, rigorous, and ethical research that also contributes meaningfully toward empowering the communities in which we work, we not only collectively examine why we do political ecology, but also share with each other our on-the-ground experience of how we do political ecology.

\section{Diverse methodologies}

Although the LCPE network has no unified methodological approach, its members employ a diversity of practices that draw on the traditions of political ecology, while continuing to bridge disciplinary divides and methodologies. Most of the researchers in our network conduct some sort of fieldwork, which grounds our analyses in the specificity of the encounters between the humans or more-than-humans with whom we study, as well as in our own positionality as subjects in those encounters. We construe 'the field' broadly, however, ranging from forests to laboratories, political hearings to city parks and agricultural fields. Because history matters in understanding present-day environmental relationships and contexts, approaches that unpack the situated history of a place often play an important role in our research (D.K. Davis 2015). Finally, as many of us engage socio-natures that complicate traditional social and environmental science methods, our practices are often pragmatic and employ creative 'mixed methods' that create dialogue across disciplinary boundaries.

Many in our network draw on approaches from science and technology studies, feminist scholarship, and decolonial methodologies to draw attention to the power dynamics inherent in researcher-researched relationships. We likewise seek ways to work more collaboratively and non-hierarchically with the publics and communities with whom we work (Edmunds et al. 2013; Gupta and Kelly 2014; Sharp 2005; Simpson 2014; Ybarra 2017). Some of us also trouble academic gatekeeping regarding what constitutes valid knowledge and who counts as a legitimate knowledge-holder, thereby destabilizing entrenched hierarchies (de la Cadena and Blaser 2018). We often employ process-based and relational approaches, including participatory action research (e.g. Goodling, Box 1), which views research dialogically, and attempts to create knowledge that can be directly put into action by relevant communities. In the Boxes below, some of LCPE's early-career scholars describe their work. These descriptions reflect a small sampling of our network, who graciously shared a bit of their own research experience with the authors. The scholars cited below honed their methods as graduate students during the first LCPE workshop in 2015, and further developed them in other regional inter-campus political ecology workshops.

\footnotetext{
${ }^{13}$ http://ppel.arizona.edu.
} 


\begin{abstract}
Ashton Wesner
Wesner uses a queer, feminist science and technology studies framework to analyze the cultural and material production of environmental and biological knowledge. This approach uses transdisciplinary methods to critique how taken-for granted categories such as "nature", "biological sex", and "gender" are maintained, and disrupted, by scientists at work in the laboratory and the field. For example, Wesner co-designs research questions about the history and politics of sexual selection with arachnologists who study jumping spider mating-behavior. She guides a team of arachnologists, feminist theorists, and social scientists to bring their situated knowledges to bear on the same theme: de-naturalizing, or making strange, foundational concepts like sex, gender, and agency. They do this by exchanging and analyzing key readings from their own disciplines in focus groups, observing one another through embedded ethnography during fieldwork and lab experiments, and conducting discursive analysis on popular science representations and peerreviewed scholarship.
\end{abstract}

\title{
Erin Goodling
}

Within a Participatory Action Research (PAR) framework, Goodling uses traditional social science methods emergently, in response to needs identified by community leaders. In this way, her research addresses interlinked theoretical, empirical, and community-driven questions. For example, while collaborating with community leaders organizing for a more just cleanup of the Portland Harbor Superfund site (a Federal designation to indicate contamination by hazardous substances and pollutants), Goodling began reading seemingly unrelated local media stories, and discovered important clues about the role of corporate power in local environmental decision-making structures. Had she not been working closely with a grassroots coalition, these insights likely would not have emerged. In turn, her analysis of the ways in which corporations were using the legal system to undermine local public agencies informed the coalition's strategy.

\section{Jeff Vance Martin}

Martin's work centers on human-wildlife conflict, specifically the "wolf question" in the American West. Over 40 semi-structured interviews with ranchers and livestock industry representatives, environmental organization leaders, and government agency employees provided qualitative data on the experiences, practices, and discursive framings of each set of actors. In contrast to extant attitudinal survey work, Martin recruited research participants through a "snowball" or respondent-driven sampling approach, which allowed him to follow the social relationships and storylines that emerged from the research process.

\section{Sophie Sapp Moore}

Moore's research examines how power shapes agrarian environments, and in particular the political ecology of agrarian change in Haiti. Moore utilizes ethnography, which she describes as a "slow methodology" that allows the time that one's questions need to unfold. Moore sees this methodological approach as an especially significant one in Haiti, where "many people who are interested in the country and its people just drop in, in a short frame of time, with short-term goals." Practicing ethnography has allowed Moore to understand how Haitians tell their history to themselves, through their cultural practices, and through the ways they live their daily lives.

\section{Jeffrey Jenkins}

Jenkins' work examines landscape meaning in American West multiple-use forest communities. In the scoping phase of his research, Jenkins enacts and reflects on his own positionality as an ecotourist in places like Stanislaus National Forest. He finds that this process facilitates his access to local narratives about histories, livelihoods, and economic activity that he would not otherwise encounter through, for instance, formal interviews. For Jenkins, practicing groundtruthing in this 
way entails a process of abduction, which helps bring power structures and knowledge production processes into iterative conversation with one another.

Box 1: Methodological approaches taken by early-career scholars.

While the methods we draw on in our individual research pursuits vary, as a collective we share a commitment to nourishing a redistributive network in our engagements with one another. To borrow from Larsen (2016) and Carter (2013: 26), we are actively working through how political ecologists can better cultivate a "region of care." We see the network structure itself as a valuable method for reworking hierarchical models of knowledge production, which are often reinforced by access barriers to participate in workshops, funding opportunities, and publishing. A network allows us to leverage the privilege afforded to those at more elite or well-funded institutions to support the inclusion of scholars at less-advantaged ones by hosting network-wide workshops with sliding scale costs, enabling a more collaborative and open sharing of knowledge and practices across institutional boundaries. LCPE has tried to model this in the organization of the meetings and events that we have hosted, in particular by making special efforts to remove barriers to participation due to cost, childcare, and housing. In practice, this means soliciting information on and meeting accessibility needs, offsetting travel expenses for those living beyond the region, facilitating free lodging, and providing quality childcare throughout the duration of the workshop.

As noted above, LCPE members have embraced collaborative organization, co-authorship, and informal peer review as key to our praxis. Network participants have organized panels drawing together graduate students, junior, and senior scholars (and often, true to the political ecology's legacy, across disciplinary boundaries). These conversations - and this manifesto - reflect a broader orientation around both science and politics as collective acts, as well as a commitment to increasing the number and variety of voices in political ecology.

\section{Visions of the future}

Though political ecology is inherently critical, in the present political and environmental moment LCPE feels particularly called to critical action. The environments we live and work in are becoming ever more inhospitable, and the political climate increasingly polarized. Thus, we are compelled not only toward intersectional critique of structural forms of oppression, but also to take a stand in these struggles as both embodied researchers and affected community members.

Tracey Osborne (2017) proposes the idea of a community of praxis toward engaged scholarship. Osborne defines this "Public Political Ecology" as "the theoretically-informed practice of a diverse set of actors (which include an important role for academics) who share environmental concerns, collaborate, and co-produce knowledge in order to guide ethical action for earth stewardship" (p. 849). As public political ecology researchers, it becomes imperative to unsettle definitions of the "public" to whom scholars are responsible, to rethink whose knowledges are worth considering, and to be accountable to the material consequences of how knowledge is distributed. This vision inspires our work to build LCPE into a community of praxis. Although we work in and on varied geographies (beyond the immediate geographic region) and with a diversity of approaches, the dialogue that has begun to develop through LCPE's network has allowed members to frame discussions around common questions, and to find points of interest from which creative endeavors may grow.

We see LCPE's geographic position as an opportunity to collectively turn our gaze on the local issues particular to the stolen land on which we live, and upon which livelihood struggles are increasingly fierce. For example, a Political Ecology Lab has emerged at the University of California Davis from connections made at the January 2018 workshop. The lab brings together students and faculty from across campus, to provide support for members' ongoing individual projects, and also to create new collaborative scholarship on local issues. At the UC Davis Political Ecology Lab's first retreat in May 2019, we collectively defined what our place-based definition of "public political ecology" would be, rooted in the potential as well as 
the problems of UC Davis as a land grant university. We explored the potential of political ecology to confront local institutional oppression and to build better futures, with an emphasis on topics most closely related to research and organizing on our campus and amongst our members (e.g. food justice, Latinx geographies, and Indigenous environmental justice). The UC Davis Political Ecology Lab has since secured funding to explore feminist approaches to public political ecology, and plans to host an event on critical political ecology approaches to food systems, engaging the large agricultural science programs on campus in critical and collegial debate.

LCPE is only beginning to establish a foundation for institutional continuity. The 2018 workshop highlighted the value of our work, building connections between generations of scholars and encouraging cross-pollination between institutions and traditions. We have laid the groundwork for a regional conference, and we have identified visions and needs around how to sustain regular programming. This kind of work requires consistent support, both interpersonal and financial; organizing has material costs. The network approach encourages a collective sharing of labor, which will be necessary to build continuity within our community. We especially see the need for mentorship and the sharing of intellectual and social capital from more established faculty members. Such support is invaluable for early career scholars and often sorely lacking. As such, we propose a series of initiatives: a program to pair mentors with junior scholars (which we implemented at the last LCPE workshop), the creation of a database for political ecology syllabi on our website, the use of the LCPE listserv as a forum for requesting support with grant writing or initiating collaborations, and a practice of inviting junior scholars and scholars of color to events with honorariums provided. Relations of physical proximity mean we can share resources beyond university borders, exceeding what is available in any one institutional space. To these ends, the network approach offers not only a sharing of practices applied to particular types of problems, but a redistribution of resources within these networks to build mutual support among scholars.

We invite you to join us in collaboration. LCPE is a network situated in the western side of North America, and though many of our us are presently concentrated in specific institutions (UC Berkeley and UC Davis in particular), we have a widely dispersed member base. We are excited by the potential to strengthen relations regionally among a wider diversity of institutions, as well as to connect with other Political Ecology networks globally like POLLEN (the Political Ecology Network). The University of Kentucky Political Ecology Working Group, responsible for the annual Dimensions of Political Ecology (DOPE) conference, has also inspired us to create ongoing regional gatherings focused on generating an accessible forum for critical engaged scholarship that centers decolonial approaches. We would like to grow LCPE in relation to and in dialogue with these other groups.

The goal of the LCPE network is not to create a unified voice, but to link a plurality of perspectives and practices toward serving those publics who are most marginalized by structural oppression and ecological violence in particular. Nonetheless, we envision LCPE's position on the Left Coast, at this rocky and often turbulent edge of Turtle Island (North America), as carrying forward a particular tradition of political ecology scholarship. We see our work as continually questioning and eroding rigid structures that hold us in specific configurations of power, while also revealing new and emergent sites for inquiry. Weathering and working this edge is sometimes lonely and harsh, so in especially dark times we choose to gather together around this collective work of building a more compassionate and emancipatory future.

\section{References}

Bauer, Jr., W.J. 2016. California through native eyes: reclaiming history. Seattle: University of Washington Press.

Blaikie, P.M. 1985. The political economy of soil erosion in developing countries. London: Longman.

Blaikie, P.M. 2008. Epilogue: towards a future for political ecology that works. Geoforum 39(2): 765-772.

Blaikie, P.M. and H.C. Brookfield. 1987. Land degradation and society. London: Methuen.

Blue Cloud, P. 1972. Alcatraz is not an island. Berkeley: Wingbow Press. 
Carroll, C. 2015. Roots of our renewal: ethnobotany and Cherokee environmental governance. Minneapolis: University of Minnesota Press.

Carter, P. 2013. Meeting place: the human encounter and the challenge of coexistence. Minneapolis: University of Minnesota Press.

Chen, M.Y. 2012. Animacies: biopolitics, racial mattering, and queer affect. Durham: Duke University Press.

Cronon, W. 1992. Nature's metropolis: Chicago and the great west. Chicago: WW Norton and Company.

Daniel, C. 1982. Bitter harvest: a history of California farmworkers, 1870-1941. Berkeley: University of California Press.

Davis, D.K. 2007. Resurrecting the granary of Rome: environmental history and French colonial expansion in north Africa. Athens: Ohio University Press.

Davis, D.K. 2015. Historical approaches to political ecology. In Perrault, T., G. Bridge and J. McCarthy (eds.). The Routledge handbook of political ecology. London and New York: Routledge. Pp. 263275.

Davis, M. 1998. Ecology of fear: Los Angeles and the imagination of disaster. New York: Metropolitan Books.

de la Cadena, M. and M. Blaser (eds.). 2018. A world of many worlds. Durham: Duke University Press.

Doshi, S. 2017. Embodied urban political ecology: five propositions. Area 49(1): 125-128.

Edmunds, D.S., R. Shelby, A. James, L. Steele, M. Baker, Y.V. Perez and K. TallBear. 2013. Tribal housing, codesign, and cultural sovereignty. Science Technology and Human Values 38(6): 801828.

Escobar, A. 1998. Whose knowledge, whose nature? Biodiversity, conservation, and the political ecology of social movements. Journal of Political Ecology 5(1): 53-82.

Escobar, A. 1999. After nature: steps to an antiessentialist political ecology 1. Current Anthropology 40(1): 1-30.

Faria, C. and S. Mollett. 2016. Critical feminist reflexivity and the politics of whiteness in the 'field'. Gender, Place and Culture 23(1): 79-93.

Finney, C. 2014. Black faces, white spaces: reimagining the relationship of African Americans to the great outdoors. Chapel Hill: UNC Press.

Flamming, D. 2005. Bound for freedom: black Los Angeles in Jim Crow America. Berkeley: University of California Press.

Flores, L.A. 2016. Grounds for dreaming: Mexican Americans, Mexican immigrants, and the making of the California farmworker movement. New Haven: Yale University Press.

Gilmore, R.W. 2007. Golden gulag: prisons, surplus, crisis, and opposition in globalizing California. Berkeley: University of California Press.

Goldstein, A. (ed.). 2014. Formations of United States colonialism. Durham: Duke University Press.

Goldstein, J.E., K. Paprocki and T. Osborne. 2019. A manifesto for a progressive land-grant mission in an authoritarian populist era. Annals of the American Association of Geographers 109(2): 673-684.

Gupta, C. and A.B. Kelly. 2014. The social relations of fieldwork: giving back in a research setting. Journal of Research Practice 10(2): 1-11.

Haraway, D. 2015. Anthropocene, capitalocene, plantationocene, chthulucene: making kin. Environmental Humanities 6: 159-165.

Hays, S.P. 1999 [1959]. Conservation and the gospel of efficiency: the progressive conservation movement, 1890-1920. Pittsburgh: University of Pittsburgh Press.

Hernández, R.D. 2015. 1968: on social, epistemic, and historiographic(?) revolutions. Kalfou 2(1): 135-46. Heynen, N. 2018. Toward an abolition ecology. Abolition: A Journal of Insurgent Politics 1: 240-247. 
Johnson, T. 1996. The occupation of Alcatraz Island: Indian self-determination and the rise of Indian activism. Urbana: University of Illinois Press.

Kahrl, W.L. 1983. Water and power: the conflict over Los Angeles water supply in the Owens Valley. Berkeley: University of California Press.

Kim, S., G.U. Ojo, R.Z. Zaidi and R.L. Bryant. 2012. Bringing the other into political ecology: reflecting on preoccupations in a research field. Singapore Journal of Tropical Geography 33(1): 34-48.

Kosek, J. 2006. Understories: the political life of forests in northern New Mexico. Durham: Duke University Press.

Krohn, J. 2019. Geographer. Humanitarian. Felon? Huffington Post 30 May. [accessed August 5 2019]. https://www.huffpost.com/entry/scott-warren-arizona-undocumentedmigrants_n_5ceee754e4b00cfa19658ebd.

Larsen, S.C. 2016. Regions of care: a political ecology of reciprocal materialities. Journal of Political Ecology 23: 159-166.

Loftus, A. 2012. Everyday environmentalism: creating an urban political ecology. Minneapolis: University of Minnesota Press.

Louis, R.P. 2007. Can you hear us now? Voices from the margin: using Indigenous methodologies in geographic research. Geographical Research 45(2): 130-139.

Martin, J.V., K. Epstein, N. Bergmann, A.C. Kroepsch, H. Gosnell and P. Robbins. 2019 in press. Revisiting and revitalizing political ecology in the American West. Geoforum https://doi.org/10.1016/j.geoforum.2019.05.006.

McCarthy, J. 2002. First world political ecology: lessons from the wise use movement. Environment and Planning A 34(7): 1281-1302.

McKittrick, K., and C.A. Woods (eds.). 2007. Black geographies and the politics of place. Brooklyn: South End Press.

Meinig, D.W. 1972. American Wests: preface to a geographical interpretation. Annals of the Association of American Geographers 62(2): 159-184.

Merchant, C. 2005. Radical ecology: the search for a livable world. London: Routledge.

Middleton, E. 2010. A political ecology of healing. Journal of Political Ecology 17(1): 1-28.

Middleton, B.R. 2015. Jahát Jatítotòdom: toward an Indigenous political ecology. In R.L. Bryant (ed.). The international handbook of political ecology. Cheltenham: Edward Elgar. Pp. 561-576.

Middleton Manning, B.R. 2018. Upstream: trust lands and power on the Feather River. Tucson: The University of Arizona Press.

Mollett, S. and C. Faria. 2013. Messing with gender in feminist political ecology. Geoforum 45: 116-125.

Moore, D.S., J. Kosek and A. Pandian (eds.). 2003. Race, nature, and the politics of difference. Durham: Duke University Press.

Moore, S.A. and P. Robbins. 2015. Nature's diverse economies: reading political ecology for economic difference. In Roelvink G., K. St. Martin and J.K. Gibson-Graham (eds.). Making other worlds possible: performing diverse economies. Minneapolis: University of Minnesota Press. Pp. 153-172.

Moore, S.S., M. Allewaert, P. Gòmez and G. Mitman. 2019. Plantation legacies. Edge Effects, 22 January.

Murphy, M. 2017. Alterlife and decolonial chemical relations. Cultural Anthropology 32(4): 494-503.

O'Connor, J. 1988. Capitalism, nature, socialism: a theoretical introduction. Capitalism Nature Socialism 1(1): 11-38.

Osborne, T. 2017. Public political ecology: a community of praxis for earth stewardship. Journal of Political Ecology 24(1): 843-860.

Peck, J. and T.J. Barnes. 2019. Berkeley in-between: radicalizing economic geography. In Barnes T.J. and E. Sheppard (eds.). Spatial histories of radical geography. Chichester: Wiley. Pp 211-246. 
Peet, R. and M.J. Watts (eds.). 2004. Liberation ecologies: environment, development and social movements. London: Routledge.

Peluso, N.L. 1992. The political ecology of extraction and extractive reserves in East Kalimantan, Indonesia. Development and Change 23(4): 49-74.

Peluso, N.L and M.J. Watts (eds.) 2001. Violent environments. Ithaca: Cornell University Press.

Pulido, L. 2002. Reflections on a white discipline. The Professional Geographer 54(1): 37-41.

Pulido, L. and J. De Lara. 2018. Reimagining 'justice' in environmental justice: radical ecologies, decolonial thought, and the Black radical tradition. Environment and Planning E: Nature and Space 1(1-2): 7698.

Restrepo, E. and A. Escobar. 2005. 'Other anthropologies and anthropology otherwise': steps to a world anthropologies framework. Critique of Anthropology 24(2): 99-129.

Ribot, J.C. and N.L. Peluso. 2003. A theory of access. Rural Sociology 68(2): 153-181.

Robbins, P. 2002. Obstacles to a First World political ecology? Looking near without looking up. Environment and Planning A 34(8): 1509-1513.

Robbins, P. 2012. Political ecology: a critical introduction. Malden, MA: Wiley-Blackwell.

Robinson, C.J. 1983. Black Marxism: the making of the Black radical tradition. Chapel Hill: University of North Carolina Press.

Rocheleau, D.E. 2008. Political ecology in the key of policy: from chains of explanation to webs of relation. Geoforum 39(2): 716-727.

Rocheleau, D.E. and D. Edmunds. 1997. Women, men and trees: gender, power and property in forest and agrarian landscapes. World Development 25(8): 1351-1371.

Safina, C. 2012. The view from Lazy Point: a natural year in an unnatural world. New York: Picador.

Santos, B. de S. 2014. Epistemologies of the south: justice against epistemicide. London: Routledge.

Sasser, J. 2018. On infertile ground: population control and women's rights in the era of climate change. New York: NYU Press.

Sauer, C.O. 1963. The morphology of landscape. In J. Leighly (ed.). Land and life: a selection from the writings of Carl Ortwin Sauer. Berkeley: University of California Press. Pp. 315-350.

Sayre, N.F. 2002. Ranching, endangered species, and urbanization in the Southwest: species of capital. Tucson: University of Arizona Press.

Sayre, N.F. 2017. The politics of scale: a history of rangeland science. Chicago: University of Chicago Press.

Schroeder, R.A., K. St. Martin and K.E. Albert. 2006. Political ecology in North America: discovering the Third World within? Geoforum 37(2): 163-168.

Schulz, K.A. 2017. Decolonizing political ecology: ontology, technology and 'critical' enchantment. Journal of Political Ecology 24 (1): 125-143.

Sharp, J. 2005. Geography and gender: feminist methodologies in collaboration and in the field. Progress in Human Geography 3: 304-309.

Simon, G.L. 2016. Flame and fortune in the American West: urban development, environmental change, and the great Oakland Hills fire. Berkeley: University of California Press.

Simpson, A. 2014. Mohawk interruptus: political life across the borders of settler states. Durham: Duke University Press.

Smith, L.T. 2012. Decolonizing methodologies: research and indigenous peoples. London: Zed Books.

Steward, J. 1972. The concept and method of cultural ecology. In Theory of cultural change. Urbana: University of Illinois Press. Pp. 30-42.

Stryker, S. 2008. Transgender history. Berkeley: Seal Press.

Sundberg, J. 2007. Reconfiguring North-South solidarity: critical reflections on experiences of transnational resistance. Antipode 39(1): 144-166. 
Sundberg, J. 2014. Decolonizing posthumanist geographies. Cultural Geographies 21(1): 33-47.

Tallbear, K. 2014. Standing with and speaking as faith: a feminist-indigenous approach to inquiry. Journal of Research Practice 10(2): Article-N17.

Vowel, C. (Âpihtawikosisân). 2016. Beyond territorial acknowledgements. Âpihtawikosisân: Law. Language. Culture. (blog)

Walker, P.A. 2007. Political ecology: where is the politics? Progress in Human Geography 31(3): 363-69.

Walker, R.A, 2004. The conquest of bread: 150 years of agribusiness in California. New York: New Press.

Watts, M.J. 1983. Silent violence: food, famine and peasantry in northern Nigeria. Berkeley: University of California Press.

Wilkinson, C.F. 1992. Crossing the next meridian: land, water, and the future of the west. Washington, DC: Island Press.

Wynter, S. 1971. Novel and history, plot and plantation. Savacou 5: 95-102.

Wynter, S. 2003. Unsettling the coloniality of being/power/truth/freedom: towards the human, after man, its overrepresentation - an argument. CR: The New Centennial Review 3(3): 257-337.

Ybarra, M. 2017. Green wars: conservation and decolonization in the Maya forest. Berkeley: University of California Press.

Zimmerer, K.S. 1995. Ecology as cornerstone and chimera in human geography. In Earle, C., K. Mathewson and M.S. Kenzer (eds.). Concepts in human geography. Lanham, Maryland: Rowman and Littlefield Publishers. Pp. 161-187. 